\title{
Kajian Strategi Peningkatan Mutu Pendidikan Anak Usia Dini
}

\author{
Nurhamsa Mahmud1, Andi Agustan Arifin², Listanti Mou ${ }^{3}$ \\ Universitas Khairun Ternate \\ Fakultas Keguruan dan Ilmu Pendidikan \\ Jl. Bandara Sultan Baabullah Kota Ternate Utara, Kotak Pos 53 Ternate 977328 \\ Email: nurhamsaaca@gmail.com
}

\begin{abstract}
Abstrak: Strategi merupakan penentuan suatu tujuan jangka panjang dari suatu lembaga dan aktivitas yang harus dilakukan guna mewujudkan suatu tujuan tertentu, disertai alokasi sumber yang ada sehingga tujuan dapat diwujudkan secara efektif dan efesien. Metode yang digunakan dalam penelitian ini dengan pendekatan studi literatur (library reseach). Menurut Zeed Mestike (2014) menyatakan bahwa metode penelitian dengan pendekatan study literatur merupakan penlitian yang serangkaian kegiatannya dengan metode pengumpulan data pustaka, buku-buku, serta tulisan yang terkait dengan judul penelitian ini. Penelitian kajian literatur yang dilakukan dapat disimpulkan bahwa pendidikan bisa dianggap berhasil dan bermutu apabila kemampuan dan sikap yang dimiliki anak berguna bagi perkembangan selanjutnya, sedangkan mutu dapat ditingkatkan apabila proses belajar yang diselenggarakan sesuai dan menunjang pencapaian tujuan. Strategi peningkatan mutu pendidikan pada anak usia dini direkomendasikan dapat dilakukan dengan strategi yang menekankan pada proses (the process oriented strategy).
\end{abstract}

Kata kunci: Strategi, Mutu Pendidikan

Abstract: Strategy determines a long-term objective of an agency and activities a specific that much be undertaken to achieve a specific purpose, along with existing resource allocation so that goals can be effectively and efficiently implemented. The method used in this study was with the introduction to the literature study (library reseach). According to zeed mestike (2014), a study method wiht the study of literature isa study that sets out a series of activities using the methodfor collecting date for libraries, books, and writings associated with the title of the study. Research on literature studies may conclude that education can be considered successful and profitable if children'sability and attitudes are useful for further development, while quality can be enhanced if the learning process is met accordingly and promotes the goal. The advenced education strategy in young children is recommended with a strategy that emphasizes the process.

Keywords: strategy, quality of education.

\section{A. Pendahuluan}

Pendidikan merupakan kebutuhan mendasar setiap manusia. Dengan pendidikan, menusia akan mampu membangun masa depan dan peradabannya. Masa depan yang cerah dan peradaban yang mampu tidak dapat dicapai tanpa adanya pendidikan. Pendidikan sebagai usaha yang strategis dan paling mendasar dalam menyiapkan sumber daya manusia yang berkualitas. Pendidikan merupakan salah satu pilar dan modal utama dalam mengantisipasi, menyongsong masa depan, karena pendidikan selalu diorientasikan untuk mengembangkan sumber daya peserta didik guna dapat berperan dimasa yang akan datang dan diarahkan kepada kebutuhan manusia.

Aktivitas pendidikan sejak awal telah menjadi cara bertindak dari sebuah masyarakat, sebagai upaya melanggengkan peradabannya. Kepada generasi yang lebih muda mereka mewariskan nilai nilai yang penting dalam kultur masyarakat tempat mereka hidup. Jika proses pewarisan ini tidak terjadi, maka nilai-nilai yang telah 
menghidupi masyarakat dan kebudayaan tersebut terancam punah dengan kematian para anggotanya. Oleh karenanya pendidikan memiliki peran penting, sebab tidak hanya menentukan keberlangsungan masyarakat, namun juga mengukuhkan identitas individu dalam sebuah masyarakat (Emosda, 2012: 3). Penerapan pendidikan kepada anak sedini mungkin, sebenarnya memuat tujuan untuk membina dan mengembangkan potensinya sejak awal agar dapat tumbuh dan berkembang secara optimal sesuai tipe kecerdasannya (Suyanto, 2005: 5).

Satu faktor yang ikut menentukan tercapainya tujuan pendidikan di sekolah adalah sumber daya manusia. Terkait dengan sumber daya manusia (SDM) sebagai sumber daya utama dalam menjalankan bidang-bidang organisasi termasuk bidang pendidikan, dikenal suatu istilah yaitu manajemen tenaga pendidik (Malayu, 2000: 4041).

Strategi guru dalam mengembangkan mutu pada proses pembelajaran mencakup penggunaan metode dan pemanfaatan berbagai sumber daya atau kekuatan dalam suatu pembelajaran. Strategi pembelajaran disusun untuk mencapai tujuan tertentu. Strategi pembelajaran didalamnya mencakup pendekatan, model, metode dan teknik pembelajaran secara spesifik (Mufarokah, 2009: 36).

Fakta di lapangan khususnya di Maluku Utara menunjukan bahwa terdapat berbagai permasalahan dalam proses pembelajaran guna peningkatan mutu pendidikan di sekolah. Berdasarkan data tahun 2016, guru PAUD di provinsi Maluku Utara yang telah memiliki ijasah S1 sebanyak 473 dan yang masih belum memiliki kualifikasi pendidikan S1 sebanyak 1056 guru (KEMENDIKBUD 2016: 32). Hal ini membutuhkan kepiawaian guru khususnya guru dengan kualifikasi non sarjana ataupun bukan sarjana PAUD.

Guru cenderung menemukan kesulitan dalam menangani anak dengan karakteristik yang berbeda-beda. Anak cenderung mengalami kesulitan dalam belajar, dan guru mengalami kesulitan dalam mencari solusi dalam membantu anak tersebut. Tak dapat dipungkiri bahwa tidak ada satu metodepun yang terbaik dalam membantu anak. Setiap anak unik, memiliki karakteristik yang beragam. Oleh sebab itu diperlukan suatu strategi dalam menolong anak yang berkesulitan belajar sehingga proses pembelajaran dapat berlangsung dengan baik dan mutu pendidikan di sekoah dapat ditingkatkan.

Berdasarkan fakta yang terjadi serta kajian literatur, maka penulis tertarik untuk mengkaji strategi peningkatan mutu pendidikan di sekoah bagi anak usia dini. Dalam artikel ini penulis memberikan solusi berbagai strategi mutu pendidikan pada anak usia dini.

\section{B. Pembahasan}

\section{Strategi Peningkatan Mutu Pendidikan di Sekolah}

Strategi merupakan penentuan suatu tujuan jangka panjang dari suatu lembaga dan aktivitas yang harus dilakukan guna mewujudkan tujuan tersebut, disertai alokasi sumber yang ada sehingga tujuan dapat diwujudkan secara efektif dan efesien. Penentuan tujuan dan aktivitas yang dilakukan bermula dari kondisi saat ini yang ada dan kondisi yang akan dicapai masa depan sebagai tujuan. Terdapat tiga perencanaan strategis yang berkaitan dengan peningkatan mutu sekolah, yaitu: 
a. Strategi yang menekankan pada hasil (the output oriented strategy)

Strategi yang menekankan pada hasil bersifat top down, di mana hasil yang akan dicapai baik kuantitas maupun kualitas telah ditentukan dari atas, bisa dari pemeritah pusat, pemerintah daerah propinsi, ataupun pemerintah daerah kabupaten/kota. Kasus di Indonesia saat ini, hasil yang herus dicapai telah dirumuskan dalam Standar Kopetensi Lulusan dan Standar Kompetensi Dasar. Untuk mencapai standar yang telah ditetapkan pemerintah juga akan menetapkan berbagai standar yang lain, seperti standar proses, standar pengelolaan, standar fasilitas, dan standar tenaga pendidik. Strategi yang menekankan pada hasil ini akan sangat efektif karena sasarannya jelas dan umum, sehingga apabila diikuti dengan pedoman, pengendalian dan pengorganisasian yang baik serta kebijakan yang memberikan dorongan sekaligus ancaman bagi yang menyimpang, strategi ini akan akan sangat efesien. Namun, dibalik kebaikan tersebut strategi ini juaga mengandung sisi kelemahan yakni akan terjadi kesenjangan yang semakin besar antara sekolah yang maju dan sekolah yang terbelakang. Sekolah yang sudah siap untuk mencapai hasil yang ditentukan akan dengan mudah mencapainya, sebaliknya sekolah yang tidak siap sulit untuk mencapai hasil yang ditentukan dan akan muncul upaya-upaya yang tidak sehat atau muncul keputus-asaan.

b. Strategi yang menekankan pada proses (the process oriented strategy)

Untuk Strategi yang menekankan pada proses muncul, tumbuh berkembang dan digerakkan mulai dari bawah, yakni sekolah sendiri. Pelaksanaan strategi ini sangat ditentukan oleh inisiatif dan kemampuan dari sekolah. Karena sekolah memilki peran yang sangat menentukan dan sekaligus pengambil inisiatif, maka akan muncul semangat dan kekuatan dari sekolah sesuai kondisi dari masing-masing sekolah. Gerakan untuk memperkuat diri dengan bekerjasama diantara sekolah akan lahir yang akan diikuti dengan munculnya berbagai inovasi dan kreasi dari bawah. Namun, strategi ini memiliki kelemahan yaitu arah dan kualitas sekolah tidak seragam, sehingga sulit untuk melihat dan meningkatkan kualitas secara nasional.

c. Strategi komprehensif (the comprehensive strategy).

Demikian pula dalam kaitan dengan strategi, muncul strategi peningkatan mutu sekolah yang ketiga yang merupakan kombinasi dari dua strategi yang sudah ada. Strategi ini disebutstrategi yang komprehensif (the comprehensive strategy). Strategi ini menggariskan bahwa hasil yang akan dicapai sekolah ditentukan secara nasional, yang diwujudkan dalam standar nasional. Untuk mencapainya maka berbagai standar yang berkaitan dengan hasil juga ditentukan sebagai jaminan hasil akan dicapai. Maka lahirlah pula standar proses, standar pengelolaan sekolah, standar guru, kepala sekolah dan pengawas, standar keuangan, standar isi kurikulum, serta standar sarana prasarana. Berdasarkan strategi ini diperkiarakan akan muncul berbagai inovasi kegiatan dari sekolah. Bahkan, tidak mustahil akan muncul kenekaragaman dalam pengelolaan sekolah. Dengan demikian kondisi dan kebutuhan lokal terakomodasi dengan strategi komprehensif. Tujuannya bersifat nasional tetapi cara mencapainya sesuai dengan kondisi lokal. Strategi peningktan mutu sekolah yang ada di Indonesia cenderung pada strategi yang ketiga ini, sebagimana dapat ditunjukkan dengan adanya berbagai standar nasional yang menjadi acuan sekolah, namun sekolah diberi kebebasan dalam bentuk kebijakan manajemen berbasis sekolah dan kurikulum berbasis kompetensi dengan kewenangan sekolah mengembangkan Kurikulum Tingkat Satuan Pendidikan (KTSP). 
Setiap strategi mengandung kegiatan yang harus dilaksanakan untuk mewujudkan tujuan yang telah ditentukan. Kegiatan ini pada intinya adalah menggerakkan semua komponen sekolah yang bermuara pada peningkatan kualitas lulusan. Strategi untuk meningkatkan mutu mencakup membangun kapasitas level birokrat, sekolah dan kelas (Kusnandi, 2017: 113).

\section{Strategi Peningkatan Mutu Dalam Pembelajaran}

Strategi adalah rencana cermat tentang suatu kegiatan guru meraih suatu target atau sasaran. Lebih lanjut dijelaskan oleh Djamarah bahwa strategi diartikan sebagai pola-pola umum kegiatan guru anak didik dalam perwujudan kegiatan belajar mengajar untuk mencapai tujuan yang digariskan (Depdiknas, 2007: 1092).

Strategi pembelajaran disusun untuk mencapai tujuan tertentu. Strategi pembelajaran didalamnya mencakup pendekatan, model, metode dan teknik pembelajaran secara spesifik (Mufarokah, 2009: 36).

Strategi pembelajaran merupakan hal yang perlu diperhatikan guru dalam proses pembelajaran. Paling tidak ada tiga jenis strategi pembelajaran yang berkaitan dengan pembelajaran, yakni:

a. Strategi pengorganisasian pembelajaran,

Strategi pengorganisasian dan strategi penyampaian, termasuk pula membuat catatan kemajuan belajar siswa.

b. Strategi penyampaian pembelajaran,

Strategi penyampaian menekankan pada media apa yang dipakai untuk menyampaikan pembelajaran, kegiatan apa yang dilakukan siswa, dan bagaimana struktur pembelajaran.

c. Strategi pengelolaan pembelajaran.

Strategi pengelolaan menekankan pada penjadwalan penggunaan setiap komponen (Uno, 2008: 45).

Strategi pembelajaran meliputi kegiatan atau pemakaian teknik yang dilakukan oleh pengajar mulai dari perencanaan, pelaksanaan kegiatan, sampai ke tahap evaluasi, serta program tindak lanjut yang berlangsung dalam situasi edukatif untuk mencapai tujuan tertentu (Iskandarwassid, 2008:9). Oleh sebab itu dapat dikemukakan empat strategi dasar dalam proses belajar mengajar yaitu sebagai berikut:

a. Mengidentifikasi serta menetapkan spesifikasi dan kualifikasi perubahan tingkah laku dan keperibadian anak didik sebagaimana yang diharapkan.

b. Memilih sistem pendekatan belajar mengajar berdasarkan aspirasi dan pandangan hidup masyarakat

c. Memilih dan menetapkan prosedur, metode, dan tehnik belajar mengajar yang dianggap paling tepat dan efektif sehingga dapat dijadikan pegangan oleh guru dalam menunaikan kegiatan mengajarnya.

d. Menetapkan norma-norma dan batas minimal keberhasilan atau keriteria atau standar keberhasilan hingga dapat dijadikan pedoman oleh guru dalam melakukan evaluasi hasil kegiatan belajar mengajar yang dilanjutkannya akan dijadikan umpan balik buat penyempurnaan sistem intruksional yang bersangkutan secara keseluruhan (Djamarah, 2006: 5-6). 
Strategi guru dalam mengembangkan proses pembelajaran pada anak merupakan suatu serangkaian rencana kegiatan yang termasuk didalamnya penggunaan metode dan pemanfaatan berbagai sumber daya atau kekuatan dalam suatu pembelajaran. Strategi pembelajaran disusun untuk mencapai tujuan tertentu. Strategi pembelajaran didalamnya mencakup pendekatan, model, metode dan teknik pembelajaran secra spesifik (Mufarokah, 2009: 36).

Strategi yang mampu mempercepat pemberdayaan peserta didik secara Maksimal. Hal ini dapat dicapai melalui langkah-langkah :

a. Mengidentifikasi problem peserta didik, baik problem personal, intlektual, maupun hubungan sosial.

b. Menerapkan pendekatan persuasif yang berorientasi pada upaya menyadarkan peserta didik.

c. Menerapkan pemberdaayaan intelektual peserta didik.

d. Membuat kondisi sekolah dan pembelajaran yang aman, nyaman, dan menarik bagi peserta didik.

e. Berupaya meningkatkan mutu pada semua aspek secara terus menerus, (Solehan 2014: 4-5).

Menurut Habibi dkk (2017: 246) dalam penelitiannya menyatakan bahwa salah satu strategi pembelajaran yang dapat dikembangkan ialah strategi pembelajaran anak usia dini berbasis multiple intelligence.

Shobri (2017: 25) menyatakan bahwa upaya yang dilakukan dalam peningkatan mutu pendidikan antara lain: mengintensifkan kegiatan bimbingan dan penyuluhan, menciptakan suasana pembelajaran yang menarik dan memberikan penghargaan bagi siswa yang berprestasi seperti hadiah dan beasiswa, mengikutsertakan pegawai yang bersangkutan pada pendidikan dan pelatihan kepegawaian, bekerja sama dengan berbagai pihak/instansi terkait dan menerapkan sistem absensi elektrik terhadap guru dan pegawai.

Bungai, (2008: 80) dalam penelitiannya menyimpulkan bahwa peningkatan mutu dan relevansi pendidikan TK diperoleh lima sebagai berikut. (a) kompetensi profesionalisme guru TK masih rendah karena latar belakang guru TK sebagian besar bukan dari PGTK, (b) sebagian besar kondisi sekolah/kelas belum mampu mendukung terjadinya proses pembelajaran yang efektif, (c) sistem monitoring (supervise dan pengawasan) terhadap proses belajar mengajar masih belum terlaksana dengan baik, (d) sebagian orang tua menginginkan anaknya lulus TK sudah lancar membaca dan sudah bisa menulis, dan (e) belum tersosialisasinya secara intensif kurikulum dan program pendidikan TK kepada orang tua dan masyarakat.

\section{Istilah Mutu Pendidikan}

Defenisi mutu memiliki pengertian yang bervariasi. Ada beberapa pendapat yang merumuskan tentang defenisi mutu, antara lain:

a. Menurut Juran, mutu adalah kecocokan penggunaan produk (fitness for use) untuk memenuhi kebutuhan dan kepuasaaan pelanggang.

b. Menurut Crosby, mutu adalah kesesuaian individual terhadap persyaratan/tuntutan. Dengan mengatakan bahwa "quality isconformance to customer requirement". 
c. Menurut Deming, mutu adalah kesesuaian dengan kebutuhan pasar atau konsumen.

d. Menurut Feigenbaum, mutu adalah kepuasaan pelanggan sepenuhnya (full customer satisfaction).

Dari beberapa defenisi diatas dapat diambil kesimpulan bahwa pengertian mutu mengandung tiga unsur, yaitu:
a. Kesesuaian dengan standar
b. Kesesuaian dengan harapan
c. Pemenuhan janji yang diberikan.

Dalam buku lain disebut bahwa, mutu dapat didefenisikan sebagai sesuatu yang memuaskan dan melampaui keinginan dan kebutuhan pelanggan.

Edward Sallis, mutu adalah sebuah filosofis dan metodologis yang membantu institusi untuk merecanakan perubahan dan mengatur agenda dalam menghadapi tekanan-tekanan eksternal yang berlebihan. Sementara sudarwan Danim menjelaskan bahwa mutu mengandung makna derajat keunggulan suatu produk atau hasil kerja, baik berupa barang dan jasa. Sedangkan dalam dunia pendidikan barnag dan jasa itu bermakna dapat dilihat dan tidak dapa dilihat, tetapi dan dapat dirasakan. Sedangkan kamus besar bahasa indonesia menyatakan mutu adalah (Ukuran), baik buruk suatu benda, taraf atau derajat kualitas. Selanjutnya Lalu Sumayang, menyatakan quality (Mutu) adalah tingkat dimana rancangan spesifikasi sebuah produk barang dan jasa sesuai dengan fungsi dan penggunaannya, disamping itu quality adalah tingkat dimana sebuah produk barang dan jasa sesuai dengan rancangan spesifikasinya.

Berdasarkan pendapat ahli diatas, dapat disimpulkan bahwa mutu (quality) adalah sebuah filosofis dan metodologis, tentang (ukuran) dan tingkat baik buruk suatu benda, yang membantu institusi untuk merencanakan perubahan dan mengatur agenda rancangan spefisikasi sebuah produk barang dan jasa sesuai dengan fungsi dan penggunaannya agenda dalam menghadapi tekanan-tekanan eksternal yang berlebihan.

\section{Dinamika Perkembangan Mutu Pendidikan}

John Bank (2000) mengatakan mutu sebagai to pau a fully satisfying customer requirements at te lowest internal cost atau pemenuhan harapan pelanggan yang terpuaskan dengan biaya paling rendah. Pengertian mutu meliputi input, proses dan autput pendidikan. Mutu juga diartikan kualitas (quality). Munurut Juran, mutu dalah kecocokan penggunaan produk untuk memenuhi kebutuhan dan kepuasaan pelanggan, sedangkan menurut Crosby mutu adalah sesuai dengan yang diisyaratkan dan distandarkan.

Sejarah pendidikan yang ada diindonesia telah memperlihatkan kepada kita bahwa pendidikan telah mengalami berbagai perubahan dan pembenahan. Pada dasarnya perubahan-perubahan terhadap hal-hal yang mempengaruhi pendidikan tersebut adalah semacam konsekuensi logis dari adanya dinamika yang terjadi dalam dunia politik dan akhirnya melahirkan sesuatu baru. Achmad Sanusi melihat mutu pendidikan dari segi: mutu hasil belajar, mutu mengajar dan mutu bahan kajian dan pelajaran. 
Upaya perbaikan kualitas pendidikan juga terus-menerus dilakukan baik secara umum maupun dengan cara-cara yang baru. Hal tersebut lebih terfokus kembali setelah diamanatkan bahwa tujuan pendidikan nasional adalah meningkatkan mutu pendidikan nasional pada setiap jenjang pendidikan. Dalam menghadapi era globalisasi industri dan perdagangan bebas yang akan datang, berbagai negara didunia, termasuk indonesia berbenah dari mempersiapkan sumber daya manusianya. Inovasi pada dunia pendidikan sangat diperluhkan utamanya menyangkut masalah peningkatan mutu. Dalam rangka meningkatkan mutu pendidikan indonesia, pemerintah terus berupaya melakukan berbagai reformasi dalam bidang pendidikan. Dan sebagai sarana untuk meningkatkan mutu pendidikan diperluhkan sebuah kurikulum.

\section{Pembelajaran Pada Anak Usia Dini}

Anak yang berada pada rentang usia 0-6 tahun (Undang- Undang Sisdiknas tahun 2003) dan sejumlah ahli pendidikan anak memberikan batasan 0-8 tahun. Pendidikan anak usia dini sudah lama kita kenal di masyarakat kita. Pendidikan ini masih dikenal dengan pra sekolah yang terdiri dari TPA, KB dan TK/RA. Rentang usia anak TPA 0-2 tahun, KB 2-4 tahun sedangkan untuk TK adalah 5-6 tahun.

Ada berbagai kajian tentang hakikat dan karakteristik anak usia dini, khususnya anak TK diantaranya oleh Bredecam dan Copple, Brener, serta Kellough sebagai berikut anak bersifat unik. Anak mengekspresikan perilakunya secara relatif spontan. Anak bersifat aktif dan enerjik juga egosentris. Anak memiliki rasa ingin tahu yang kuat dan antusias terhadap banyak hal. Anak bersifat eksploratif dan berjiwa petualang. Anak umumnya kaya dengan fantasi. Anak masih mudah frustrasi. Anak masih kurang pertimbangan dalam bertindak. Anak memiliki daya perhatian yang pendek. Masa anak merupakan masa belajar yang paling potensial. Anak semakin menunjukkan minat terhadap teman (Yus, 2011: 1-3).

Pembelajaran pada dasarnya merupakan upaya untuk mengarahkan anak didik ke dalam proses belajar sehingga mereka dapat memperoleh tujuan belajar sesuai dengan apa yang diharapkan. Untuk mencapai hal tersebut seorang guru dapat menerapkan sistem pembelajaran yang melibatkan siswa secara aktif yang disebut sistem pembelajaran aktif (Djamarah, 2006: 7).

Penerapan pendidikan kepada anak sedini mungkin, sebenarnya memuat tujuan untuk membina dan mengembangkan potensinya sejak awal agar dapat tumbuh dan berkembang secara optimal sesuai tipe kecerdasannya (Suyanto, 2005: 5).

Dalam proses belajar mengajar Peran guru amat sangat banyak. Berikut ini dikemukan peranan guru dijelaskan menurut pendapat Prawoto:

a. Peran guru sebagai pembimbing.

Peran guru sebagai pembimbing ini lebih diutamakan, karena kehadiran guru disekolah tersebut merupakan kehadirannya untuk membimbing peserta didik menjadi manusia cakap, dewasa dan mempunyai sikap yang arif. Tanpa bimbingan seorang guru, tentunya peserta didik akan mengalami berbagai kesulitan dalam menghadapi perkembangan dan perubahan dirinya. kelemahan peserta didik menyebabkan lebih banyak tergantung pada bantuan guru. Tetapi dengan beriringnya waktu peserta didik akan mampu menjadi pribadi yang lebih mandiri tentunya dalam pengawasan guru. 
b. Guru sebagai Fasilitator.

Peran Guru sebagai fasilitator ini hendaknya memberikan fasilitas yang dapat memungkinkan dan memberi kemudahan kepada peserta didiknya dalam belajar. Menciptakan lingkungan belajar yang menyenangkan, jika suasana ruang kelas yang pengap, meja dan kursi yang berantakan tentunya membuat anak malas dalam belajar dan tidak konsentrsi dalam mengikuti pembelajaran.

c. Peran guru sebagai mediator.

Guru sebagai mediator ini hendaknya memiliki pengetahuan dan pemahaman yang baik tentunya tentang media pendidikan dalam berbagai bentuk, sumber dan jenisnya, baik media nonmaterial atau materil. Media berfugsi sebagai alat bantu komunikasi yang berguna untuk mengefektifkan proses interaksi edukatif. Keterampilan dan kemampuan dalam menggunakan semua media tersbut diharapkan media tersebut digunakan oleh guru tentunya disesuaikan dengan pencapaian tujuan pembelajaran. Sebagai itu, guru sebagai mediator, dapat diartikan sebagai penengah dalam proses belajar peserta didik. Jika dalam metode diskusi, peranan guru yaitu sebagai penengah, atau sebagai pengatur jalannya proses kegiatan diskusi.

d. Peranan guru sebagai motivator.

Guru Sebagai motifator ini hendaknya guru lebih bisamemoifasi anak didik agar lebih bersemangat dan aktif dalam mengikuti pembelajaran (Zakiya dan Nurhafizah, 2019: 361).

Menurut Rogers, keberhasilan guru yang sebenarnya menekankan pada tiga kualitas dan sikap yang utama, yaitu: (1) guru yang memberikan fasilitas untuk perkembangan anak menajdi manusia seutuhnya, (2) membuat suatu pelajaran menjadi berharga dengan menerima perasaan anak-anak dan kepribadian dan percaya bahwa yang lain dasarnya layak dipercaya membantu menciptakan suasana selam belajar, (3) mengembangkan pemahaman empati bagi guru yang peka / sensitif untuk mengenal perasaan anak-anak di dunia. Peran guru di dalam kelas boleh jadi bagian yang paling penting dari rencana pelajaran yang tak terlihat. Kekritisan dalam menentukan keefektifan dan kualitas dari perawatan dan pendidikan utuk anak kecil. Guru mungkin merupakan faktor yang paling penting dalam mendidik dan berpengalaman merawat anak (Pusari 2013: 120).

Bungai, (2008: 80) dalam penelitiannya menyimpulkan bahwa peningkatan mutu dan relevansi pendidikan TK diperoleh lima sebagai berikut. (a) kompetensi profesionalisme guru TK masih rendah karena latar belakang guru TK sebagian besar bukan dari PGTK, (b) sebagian besar kondisi sekolah/kelas belum mampu mendukung terjadinya proses pembelajaran yang efektif, (c) sistem monitoring (supervise dan pengawasan) terhadap proses belajar mengajar masih belum terlaksana dengan baik, (d) sebagian orang tua menginginkan anaknya lulus TK sudah lancar membaca dan sudah bisa menulis, dan (e) belum tersosialisasinya secara intensif kurikulum dan program pendidikan TK kepada orang tua dan masyarakat.

Berdasarkan kajian literatur terlihat jelas bahwa dalam meningkatan mutu pendidikan pada anak usia dini perlu memperhatikan karakteristik anak yang unik, berbeda dengan orang dewasa. Dalam peningkatan mutu pendidikan terdapat dua hal yang menjadi sorotan yakni peningkatan mutu disekolah dan lebih khusus peningkatan mutu pada proses pembelajaran. Dalam kajian literatur dapat disimpulkan bahwa berbagai elemen yang terlibat dalam pendidikan turut 
andil dalam peningkatan mutu pendidikan, yakni pemangku kebijakan dalam hal ini pemerintah, kepala/pengelola sekolah dan yang tidak kalah penting peran guru dalam kegiatan pembelajaran yang menghasilkan lulusan yang berkompeten, siap untuk melanjutkan pendidikan ke jenjang yang lebih tinggi. Terdapat beberapa strategi yang ditawarkan dalam kajian ini yakni: strategi yang menekan pada hasil, proses dan strategi komprehensif. Strategi peningkatan mutu pendidikan pada anak usia dini direkomendasikan dapat dilakukan dengan strategi yang menekankan pada proses (the process oriented strategy). Hal ini dikarenakan bahwa pada pembelajaran anak usia dini lebih menekankan pada kegiatan (proses) pembelajaran dari pada produk, mengingat bahwa anak masih tergolong individu yang masih dalam tahap berkembang. Sehingga tidak menekan untuk melihat produk yang dihasilkan.

\section{Simpulan}

Berdasarkan kajian literatur, dapat disimpulkan bahwa pendidikan bisa dianggap berhasil dan bermutu apabila kemampuan dan sikap yang dimiliki anak berguna bagi perkembangan selanjutnya, sedangkan mutu dapat ditingkatkan apabila proses belajar yang diselenggarakan sesuai dan menunjang pencapaian tujuan. Strategi peningkatan mutu pendidikan pada anak usia dini direkomendasikan dapat dilakukan dengan strategi yang menekankan pada proses (the process oriented strategy).

\section{DAFTAR PUSTAKA}

Bungai Joni, 2008, Peningkatan Pemerataan, Mutu, Relevansi, Tata Kelola Dan Akuntabilitas Pendidikan Taman Kanak-Kanak Jurnal Ilmu Pendidikan, Jilid 15, Nomor 2, Juni 2008, hlm. 74-81

Djamarah Syaiful Bahri, 2006. Strategi Belajar Mengajar, Jakarta: Rineka Cipta

Depdiknas, 2007Kamus Besar Bahasa Indonesia Jakarta: Balai Pustaka

Emosda, 2012. Penanaman Nilai-nilai Kejujuran dalam Menyiapkan Karakter BangsaVol. X, No. 1, Januari-Juni 2012. Skripsi Universitas Jambi

Kusnandi, 2017 Konsep Dasar dan Strategi Penjaminan Mutu Pendidikan: Sebagai Review Kebijakan Mutu Pendidikan, Indonesian Journal of Education Management and Administration Review. 2017 December, Volume 1 Number 2.

KEMENDIKBUD, 2016 Kementerian Pendidikan Dan Kebudayaan Ministry Of Education And Culture Pusat Data Dan Statistik Pendidikan Dan Kebudayaan Center For Educational Data And Statistics And Culture 2016, -Jakarta: MoEC, 
https://bulelengkab.go.id/assets/instansikab/126/bankdata/indonesiaeducational-statistics-20152016-72.pdf.

Hasibuan Malayu. 2007. Manajemen Sumber Daya Manusia. Jakarta: Bumi Aksara.

Habibi Yuliana, Srifariyati, Hafiedh Hasan, Muhamad Rifa'i Subhi 2017. Strategi Pembelajaran Anak Usia Dini Berbasis Multiple Intelligence Jurnal Madaniyah, Volume 7 Nomor 2 Edisi Agustus 2017 ISSN (printed) : 2086-3462

Iskandarwassid dan Dadang Sunendar, 2008. Strategi Pembelajaran Bahasa, Bandung: Remaja Rosdakarya

Mufarokah Anissatul, 2009. .Strategi Belajar Mengajar, Yogyakarta: Teras 